\title{
Economic efficiency and soybean yield due to the use of different fungicide combinations
}

\author{
Daniel Franke Knebel ${ }^{1}$, Diecson Ruy Oroslin da Silva ${ }^{1}$, Gustavo Henrique Demari ${ }^{2}$, Ivan Ricardo Carvalho ${ }^{2}$, \\ Vinícius Jardel Szareski ${ }^{2}$, Lucian Alex dos Santos ${ }^{2}$, Alan Junior de Pelegrin ${ }^{2}$,Dionei Schmidt Muraro ${ }^{1}$, \\ Mauricio Horbach Barbosa ${ }^{2}$, Antonio David Bortoluzzi da Silva ${ }^{1}$, Francine Lautenchleger ${ }^{3}$, João Roberto \\ Pimentel $^{2}$, Cristian Troyjack ${ }^{2}$, Francisco Amaral Villela ${ }^{2}$, and Velci Queiróz de Souza ${ }^{4}$
}

${ }^{1}$ Universidade Federal de Santa Maria, RS, Brazil

${ }^{2}$ Universidade Federal de Pelotas, Capão do Leão, RS, Brazil

${ }^{3}$ Universidade Tecnológica Federal do Paraná Campus Dois Vizinhos, PR, Brazil

${ }^{4}$ Universidade Federal do Pampa, Dom Pedrito, RS, Brazil

\section{*Corresponding authors: carvalho.irc@gmail.com}

\begin{abstract}
In Brazil, Asian rust is the main disease that affects the soybean crop, which is responsible for the great inventiveness of financial resources with fungicides to control this pathogen. The objective of this work was to evaluate the grain yield and economic viability of the different combinations of fungicides used in the soybean crop. The experiment was conducted in the 2014/2015 agricultural year in the experimental field located in the municipality of Campo Novo-RS, Brazil. The treatments used correspond to 15 combinations of fungicides, and these were applied at different times during the soybean cycle. The characters measured weremass of 1000 seeds, grain yield, gross income, fungicide cost, total cost, net income, income gain and profitability. The grain yield of soybeans was reduced by $35 \%$ due to the absence of fungicide applications. Combinations of fungicides that provide the highest yields and profitability for soybean are based on the use of different active principles such asstrobilurins and carboxamides.
\end{abstract}

Keywords: agrarian sciences, phytosanitary management, economic efficiency.

Abbreviation:kg ha ${ }^{-1}$ _kilograms per hectare;US\$_United States Dollar;r_correlation, \%_percentage; $\mathrm{CO}_{2}$ carbon dioxide

Introduction

The soybean (Glycine max (L.) Merril) stands out as the most important oilseed crop in the world due mainly to its nutritional and industrial characteristics, cultivation capacity in different latitudes, soils and climatic conditions. Soy is a strong component of the Brazilian economy, with grain production reaching 114 million tons, in the 2016/2017 harvest (Conab, 2017).

Among the main factors that limit the productive potential is the action of pathogens. A large number of diseases caused by fungi, bacteria, nematodes and viruses have been reported in Brazil (Yorinori, 1986). Almeida et al. (2005), reports that in Brazil approximately forty diseases affect the soybean crop, having a great economic importance for certain regions and agricultural crops.

Among the factors that negatively affect soybean yield is the susceptibility of some cultivars due to the incidence of diseases, monoculture and climatic conditions. In this way, it is justified the use of different measures to minimize losses through the control of diseases involving an integrated management (Szareskiet al., 2016; Ferrari et al., 2016; Meier et al., 2016; Carvalho et al., 2016). Among the main techniques are the use of resistant cultivars, seed treatments, balanced mineral fertilization, use of fungicides in the area and crop rotation (Balardin, 1999; Pelegrin et al., 2017; Gabriel et al., 2018).

The severity of fungal diseases in soybean crop occurs due to the greater susceptibility characteristic of some genotypes. While the breeding promotes the increase of the productive potential of the plants and these may show less phenotypic plasticity in relation to diseases, in the same way, the lower efficiency expressed by some chemical groups of fungicides. The use of fungicide control is the main method used by farmers, as it is characterized as a fast, practical and efficient means to minimize the action of disease-causing pathogens in cultivated plants (Oliveira, 2002; Pelegrin et al., 2016).

The grain yield is related to the photosynthetic efficiency, photosynthetically active leaf area and the leaf area index, in this way, it is sought to minimize leaf tissue losses through preventive and curative chemical control, in order to maximize the accumulation of assimilates and grain yield of the crop (BergaminFilho et al., 1997; Rigo et al., 2018).

The fungicides currently used correspond to the chemical compounds of protective, curative and systemic action (Juliatti et al., 2010). In this context, the use of mixtures can increase the efficiency of disease control. According to Sinclair and Hartman (1995), fungicide applications must be sequential with short time intervals, to allow a residual 
active principle in the plant where it guarantees the reduction of the injuries caused by pathogens that affect the leaf area of the plant. Applications should be weighted rationally, making it economically feasible and with minimal damage to the environment and human health (Godoy andCanteri, 2004). The objective of this work was to evaluate the grain yield and economic viability of the different combinations of fungicides used in the soybean crop.

\section{Results and discussion}

\section{Analysis of variance}

From the results of the analysis of variance (Table 2), it was observed that for both variables, grain yield and mass of one thousand seeds, there was a significant effect of fungicide application in soybean. From the values of the coefficients of variation obtained below, these were lower than $5 \%$, where they revealed high experimental precision for this study (Pimentel Gomes, 2009).

\section{Effect of fungicides}

For the mass of a thousand grains the treatments that obtained the best results were I, VIII, XII and XIV (Table 3). These treatments have in common two intermediary applications of the fungicide Azoxystrobin + Benzovindiflupyr. All the treatments differed from the treatment that represents the absence of fungicide application (VII), emphasizing the importance of the application as a tool to maintain the productive potential of the soybean crop. A study revealed that the character mass of a thousand grains is more sensitive to the effects of diseases when compared to grain yield (Gaspareto et al., 2011; Carvalho et al., 2017; Ferrari et al., 2018)

Grain yield showed that many combinations of fungicides did not differ, where the best results were expressed by treatments I, IV, V, VIII, X, XI, XII, XIV and XV, in this way, the farmer has a series of fungicides which showed good efficiency in disease control, where all of them had yield above $5100 \mathrm{~kg} \mathrm{ha}^{-1}$ (Table 3). It was observed that in all the treatments that stood out, three or more chemical groups were carried out.

The largest magnitudes for grain yield were revealed by the association of two or more active ingredients of the strobilurin group. Fagan (2010) defined the grain yield gain due to the use of strobilurin fungicides in relation to the other chemical groups for the phytosanitary control of the soybean crop. These results, who obtained higher grain yields in treatments with mixtures of different chemical groups (Blum et al., 2002; Follmann et al., 2017; Szareski et al., 2017; Rigo et al., 2018).

From the results of grain yield, it can be observed that the great majority of fungicide treatments were efficient in the control of soybean diseases. The treatments with the lowest yields were IX, XIII and VII, and the first one received only Mancozeb application in the four applications, proving not to be an interesting practice for the application of only one chemical group. Regarding the chemical groups of the fungicides, it was observed that the treatments with the same chemical groups (I and III) obtained different performances, and treatment $I$ increased the grain yield of soybean by $13.4 \%$ in relation to treatment III. This result is due to the responses in phytosanitary control to the same chemical groups. Embrapa (2014) showed that the fungicide Azoxystrobin and Benzovindiflupyr increased grain yield by $11 \%$ compared to the fungicide Piraclostrobin + Fluxapiroxade.

The chemical groups Carboxamides and Dithiocarbamates when associated with other groups presented the best results of grain yield. These groups act with different modes of action, distinct sites of action in pathogens, improve disease control and maintain the photosynthetic area of plants over time. Carboxamide is a specific site fungicide that acts on the inhibition of the enzyme succinate dehydrogenase, this new chemical group showed better results than the other chemical groups in the control of Phakopsorapachyrhizi (Embrapa, 2014; Zanatta et al., 2018; Aisenberg et al., 2018). Dithiocarbamates are multi-site fungicides that act on several processes vital to pathogens, being an excellent tool to increase the efficiency of systemic fungicides and disease management (Silva, 2015; Zimmer et al., 2016).

From the results, many fungicides with good efficiency were observed, mainly when they were used in associations with other active principles. The presence of the fungicide Azoxystrobin and Benzovindiflupyr resulted in high grain yields, this efficiency is due to this chemical group being new in the soybean agricultural scenario. Figure 2 shows the linear association between grain yield and the mass of one thousand seeds, it was possible to reveal a positive correlation between these variables $(r=0.92)$, indicating that the increment of the grain mass results in increases in grain yield of soybeans.

\section{Economic analysis}

For the economic analysis of the application of the different combinations of fungicides the treatment with only four applications of Mancozeb(IX) showed the lowest cost (US\$29.92), revealing a cost amplitude from US\$56.26 to US\$ 65.05per hectare sown. The net yield of soybean showed the best results for treatments XIV, XII and XV. On the other hand, treatment VII, which represents the absence of application and XIII, obtained the lowest profits per hectare. Treatments IX, III, II, VI and V presented an amplitude of US\$926.93 to US\$1086.07.

Net gains were observed in relation to the absence of fungicide application (VII), ranging from 16.9 to $72 \%$. Gaspareto et al. (2011), obtained an increase from 77 to $210 \%$ in profitability due to the use of fungicides. The worst costs were obtained with treatments XIII, IX and III (US\$ 104.18 , US\$ 241.45 and US\$275.78), respectively. Out of the profitability values from the values invested in the fungicides, it can be observed that treatment IX did not reveal efficient performance, but it obtained a higher profitability, where each US\$ 1.00 invested resulted in US\$ 8.07.This result is due to the low cost of the fungicide used, which reflected in increments on the net yield of the soybean. It is considered that the use of fungicides in soybean is of vital importance, however, the number of applications, the active principle and the mixtures dynamics should be considered, since it is necessary to maximize profitability and minimize soybean production costs. 
Table 1. Soil attributes referring to depth 0.0 and 0.1 meters sampled at the time of the experiment implantation.

\begin{tabular}{|c|c|c|c|c|c|c|c|c|}
\hline \multicolumn{9}{|c|}{ Attributes } \\
\hline $\mathrm{pH}$ & O.M* & K & $P$ & $\mathrm{Ca}$ & $\mathrm{Mg}$ & CEC & BS & Al \\
\hline $1: 1$ & $\%$ & \multicolumn{2}{|c|}{$---\mathrm{mg} \mathrm{dm}^{-3}$--- } & \multicolumn{3}{|c|}{---- cmolcdm ${ }^{-3}$} & ----- o & \\
\hline 5.94 & 4 & 234.3 & 13.20 & 7.20 & 2.50 & 13.80 & 75.00 & 0.00 \\
\hline
\end{tabular}

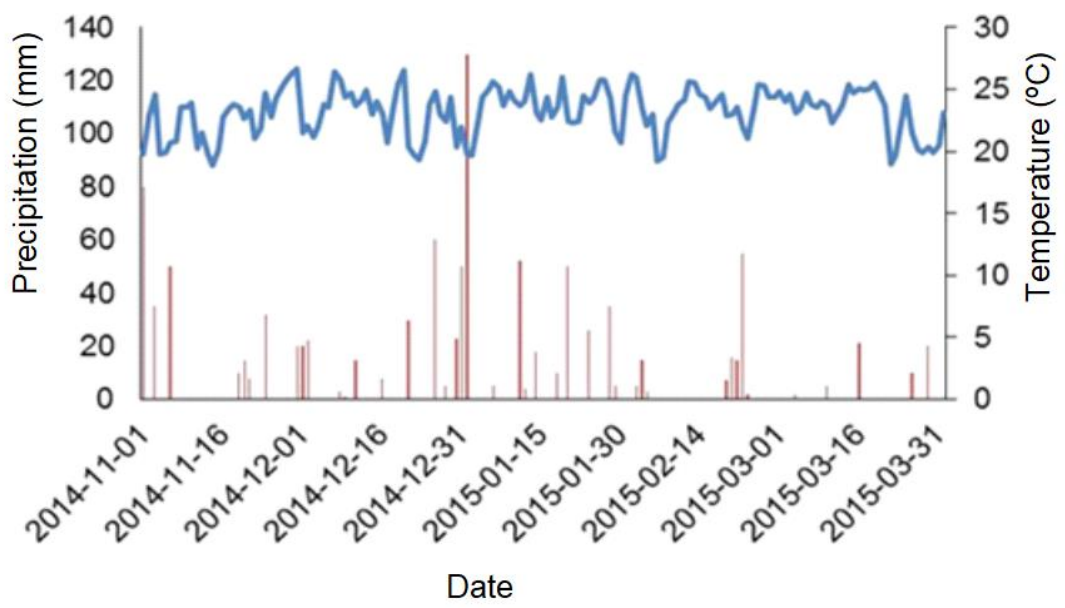

Fig 1. Climatic information (precipitation and average air temperature) from November 2014 to March 2015.

Table 2.Summary of the analysis of variance for the yield and mass of one thousand soybean seeds.

\begin{tabular}{llcc}
\hline \multirow{2}{*}{ VF } & \multirow{2}{*}{ DF } & \multicolumn{2}{c}{ Mean Square } \\
\cline { 3 - 4 } & & Mass of 1000 seeds & Grainyield \\
\hline Blocks & 5 & $21.73^{*}$ & $345.287 .50^{*}$ \\
Treatments & 14 & $838.01^{*}$ & $1.821 .371 .01^{*}$ \\
Residue & 70 & 5.25 & 38.979 .21 \\
\hline CV $(\%)$ & & 1.61 & 3.99 \\
\hline
\end{tabular}

*Significant at $5 \%$ of probability by the $\mathrm{F}$ test.

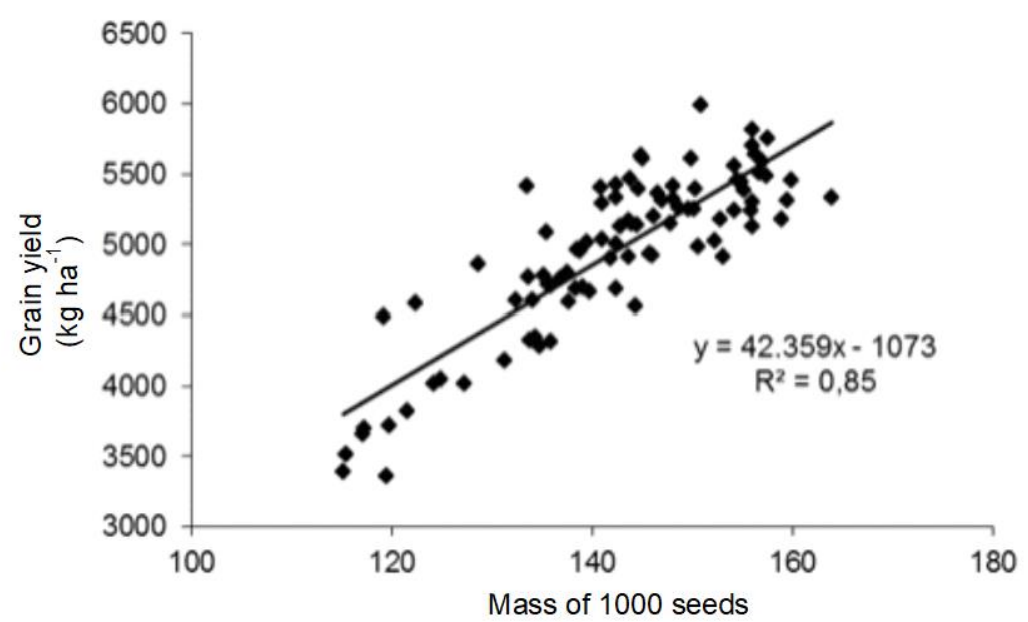

Fig 2. Linear correlation between grain yield and the mass of one thousand grains of soybean. 
Table 3. Averages for the mass of one thousand seeds and grain yield of the soybean as a function of different combinations of fungicide applied in aerial part.

\begin{tabular}{|c|c|c|}
\hline Treatments & Mass of 1000 seeds & $\begin{array}{l}\text { Grainyield } \\
-{ }_{-}\end{array}$ \\
\hline 1 & $157.80 \mathrm{a}$ & $5345.50 \mathrm{a}$ \\
\hline II & 136.98 ef & $4812.14 \mathrm{bcd}$ \\
\hline III & $136.31 \mathrm{ef}$ & $4627.40 \mathrm{~cd}$ \\
\hline IV & $142.72 \mathrm{~cd}$ & $5173.67 a b$ \\
\hline V & $143.22 \mathrm{c}$ & $5105.62 \mathrm{ab}$ \\
\hline VI & 138.46 de & 4908.15 bc \\
\hline VII & $117.38 \mathrm{~h}$ & $3555.12 \mathrm{f}$ \\
\hline VIII & $154.64 \mathrm{a}$ & 5381.57 a \\
\hline IX & $132.50 \mathrm{f}$ & $4431.53 \mathrm{de}$ \\
\hline$x$ & $145.78 \mathrm{bc}$ & $5330.01 \mathrm{a}$ \\
\hline$X I$ & $144.83 \mathrm{bc}$ & $5164.19 a b$ \\
\hline XII & $154.35 \mathrm{a}$ & $5422.98 \mathrm{a}$ \\
\hline XIII & $123.25 \mathrm{~g}$ & $4161.49 \mathrm{e}$ \\
\hline XIV & $156.30 \mathrm{a}$ & $5455.04 \mathrm{a}$ \\
\hline $\mathrm{XV}$ & $148.88 \mathrm{~b}$ & $5400.40 a$ \\
\hline
\end{tabular}

Table 4. Economic analysis of the application of different combinations of fungicides applied on the aerial part of the soybean.

\begin{tabular}{|c|c|c|c|c|c|c|}
\hline Treatments & Gross income & Fungicide cost & Total cost* & $\begin{array}{l}\text { Net income } \\
\left(\text { US\$ ha }{ }^{-1}\right)\end{array}$ & Income gain & Profitability \\
\hline$\overline{\mathrm{VII}}$ & 1100.62 & 0.00 & 414.86 & 685.76 & 0.00 & 0.00 \\
\hline XIII & 1288.39 & 71.21 & 486.07 & 802.32 & 116.56 & 0.51 \\
\hline IX & 1371.99 & 29.92 & 444.78 & 927.21 & 241.45 & 2.50 \\
\hline III & 1432.63 & 56.23 & 471.09 & 961.54 & 275.78 & 1.52 \\
\hline$\|$ & 1489.83 & 64.19 & 479.05 & 1010.78 & 325.02 & 1.57 \\
\hline VI & 1519.55 & 64.19 & 479.05 & 1040.50 & 354.75 & 1.71 \\
\hline V & 1580.69 & 79.59 & 494.46 & 1086.23 & 400.47 & 1.56 \\
\hline IV & 1601.76 & 71.92 & 486.78 & 1114.98 & 429.22 & 1.85 \\
\hline$X I$ & 1598.82 & 68.67 & 483.54 & 1115.28 & 429.53 & 1.93 \\
\hline$x$ & 1650.16 & 87.26 & 502.12 & 1148.04 & 462.28 & 1.64 \\
\hline VIII & 1666.12 & 94.77 & 509.63 & 1156.49 & 470.73 & 1.54 \\
\hline I & 1654.95 & 78.98 & 493.84 & 1161.12 & 475.36 & 1.86 \\
\hline$x V$ & 1671.95 & 93.63 & 508.50 & 1163.46 & 477.70 & 1.58 \\
\hline XII & 1678.94 & 93.02 & 507.88 & 1171.06 & 485.30 & 1.62 \\
\hline XIV & 1688.87 & 91.95 & 506.81 & 1182.06 & 496.30 & 1.67 \\
\hline
\end{tabular}

${ }^{*}$ The total cost was calculated from all expenditures with inputs applied throughout the soybean cycle that resulted in a value of US\$414.86, plus the value of fungicide treatments.

\section{Materials and methods}

\section{Plant material}

The experiment was conducted in the 2014/2015 agricultural year in the experimental field of CooperativaTritícolaMista Campo Novo Ltda , located in the municipality of Campo Novo-RS, Brazil. The coordinates are corresponded to latitude $27^{\circ} 40^{\prime} 40$ "S and longitude $53^{\circ} 49^{\prime} 54^{\prime \prime} \mathrm{W}$, with an average elevation of 483 meters. The climate of the region is characterized as Cfa, subtropical humid, according to Köppen (Maluf, 2000). Climatological information was obtained daily through the meteorological station provided by the AgroDetecta system. The soil of the experimental area is classified as typical ferric red Latosol (Table 1).

The experimental design was a randomized block design, where the treatments were arranged in six replicates.

\section{Combinations of fungicides used}

The treatments used correspond to 15 combinations of fungicides, and these were applied at different times during the soybean cycle (Supplementary table 1).

The treatments were applied with $\mathrm{CO}_{2}$ pressurized backpack type sprayer, equipped with a three meter spray bar and fan-type nozzles (XR 11002). The spray volume used was 200 $\mathrm{L} \mathrm{ha}^{-1}$ in all applications. During the crop cycle four fungicide applications were performed $(01 / 07 / 2015,01 / 26 / 2015$, $02 / 12 / 2015$ and $02 / 26 / 2015$ ). When the crop reached full maturation stage (first half of April 2015), the plots were harvested with a plot harvester.

\section{Management and farming practices}

The experimental units consisted of four lines of eight meters in length. For the measurement of the variables, the two central lines of each unit were considered, with a total area of $8 \mathrm{~m}^{2}$. The cultivar NA5909RG of approximately 130 days cycle was used. The predecessor crop was wheat, 
where it was sown in a no-tillage system in the second half of November, with 17 seeds $\mathrm{m}^{-1}$ distributed, with a final plant population of 283,961 plants $\mathrm{ha}^{-1}$. The basic fertilization used was $18.2 \mathrm{~kg}$ of $\mathrm{N} \mathrm{ha}^{-1} ; 88.4 \mathrm{~kg}$ of $\mathrm{P}_{2} \mathrm{O}_{5} \mathrm{ha}^{-1}$ and $31.2 \mathrm{~kg}$ of $\mathrm{K}_{2} \mathrm{O} \mathrm{ha}{ }^{-1}$. For top dressing and at 40 days after emergence, $60 \mathrm{~kg}$ of $\mathrm{K}_{2} \mathrm{O} \mathrm{ha}^{-1}$ were applied.

\section{Measured characters}

After harvesting, the data were adjusted to $13 \%$ of moisture and expressed in $\mathrm{kg} \mathrm{ha}^{-1}$, the mass of one thousand grains was measured by manual counting of eight replicates of one hundred seeds, results in grams (g).

For the economic analysis, the mean values obtained from the 6 replicates of each treatment were used, and the cost of production was initially determined through the cost estimate, which was the same for all treatments.

After that the gross yield of each treatment was determined by multiplying grain yield values by the mean value of soybean that has been applied in the region (US\$18.57 bag $\left.{ }^{1}\right)$. The average yield and yield gain were calculated by subtracting the values obtained in each treatment by the treatment results without application of fungicide (T7)

\section{Statistical analysis}

The data were submitted to analysis of variance at $5 \%$ of probability. The significant characters were compared by Tukey. Later the linear correlation was carried out with the purpose of identifying the tendency of association among the characters. For the economic analysis, the mean values of each treatment were used, and the costs were initially determined.

\section{Conclusion}

The grain yield of soybeans is reduced by $35 \%$ due to the absence of fungicide applications.Combinations of fungicides that provide the highest yields and profitability for soybean are based on the use of different active principles, strobilurins and carboxamides.

\section{Acknowledgements}

To CNPq (National Council for Scientific and Technological Development) and Capes (Coordination for the Improvement of Higher Education Personnel), for financial support.

\section{References}

Almeida AR, Ferreira LP, Yorinori JT, Silva JFV, Henning AA, Godoy CV, Costamilan LM, Meyer MC (2005) Doenças da soja. In: KimatiH, Amorim L, Bergamin Filho A, Camargo LEA, Resende, JAM. Manual de Fitopatologia. 2(4): 569588.

Aisenberg GR, Koch F, Pimentel JR, Troyjack C, Dubal ITP, Santos LA, Demari GH, Szareski VJ, Villela FA, Martinazzo EG, Pedo T, Aumonde TZ (2018) Soybeangrowth, solar energyconversionandseedvigouraffectedbydifferentnitrog en (N) doses. Aust J CropSci. 12: 343-349.

Balardin RS (1999) Controle de doenças na parte aérea da cultura da soja. Santa Maria. UFSM.
Bergamin Filho A, Carneiro SMTPG, Godoy CV, Amorim L, Berger RD, Hau B (1997) Angular leaf spot of Phaseolus beans: relationships between disease, healthy leaf area, and yield. Phytopathology. 87: 506-515.

Blum LEB, Reis EF, Prade AG, Tavela VJ (2002) Fungicidas e mistura de fungicidas no controle do oídio da soja. Fitopat Brasi. 27(2): 216-218.

Carvalho IR, Nardino M, Demari GH, Szareski VJ, Follmann $\mathrm{DN}$, Pelegrin AJ, Ferrari M, Olivoto T, Barbosa MH, Oliveira AC, Maia LC, Souza VQ (2017) Relations among phenotypic traits of soybean pods and growth habit. Afr J Agric Res. 12: 450-458.

Carvalho IR, Nardino M, Demari GH, Bahry CA, Szareski VJ, Pelissari G, Ferrari M, Pelegrin AJ, Oliveira AC, Maia LC, Souza VQ (2016) Bisegmented regression, factor analysis and AMMI applied to the analysis of adaptability and stability of soybean. Aust J Crop Sci. 10: 1410-1416.

Conab (2017) Acompanhamento da Safra Basileira de grãos, Primeiro levantamento, October, 2017. 4(1). Brasília.

Embrapa (2014) Eficiência de fungicidas para o controle da ferrugem-asiática da soja, Phakopsorapachyrhizi, na safra 2013/14: Resultados sumarizados dos ensaios cooperativos, C. T. 103, Londrina PR.

Fagan EB, Neto DD, Vivian $R$, Franco RB, Yeda MP, Massignam LF, Oliveira RF, Martins KV (2010) Efeito da aplicação de piraclostrobinana taxa fotossintética, respiração, atividade da enzima nitrato redutase e produtividade de grãos de soja. Bragantia. 69(4): 771-777.

Ferrari M, Pelegrin, AJ, Nardino M, Carvalho IR, Szareski VJ, Olivoto T, Belle R, Oliveira AC, Maia LC, Souza VQ (2016) Evaluation of soybeans genotypes in field environments of Rio Grande do Sul state, Brazil. Int J Curr Res. 8: 3838338392.

Ferrari M, Pelegrin AJ, Carvalho IR, Nardino M, Szareski VJ, Olivoto T, Rosa TC, Follmann DN, Pegoraro C, Oliveira AC, Maia LC, Souza VQ (2018) Path analysis and phenotypic correlation among yield components of soybean using environmental stratification methods. Aust J CropSci. 12: 193-202.

Follmann DN, Cargneletti Filho A, Souza VQ, Nardino M, Carvalho IR, Demari GH, Ferrari M, Pelegrin AJ, Szareski VJ (2017) Linear relations among traits in off-season soybean. Revista de Ciências Agrárias (Lisboa). 40: 213-221.

Gabriel M, Muraro DS, Rosa GM, Wastowski AD, Kulczynski SM, Silva JC, Carvalho IR, Szareski VJ, Stumm JO (2018) Chemical control of Asian soybean rust and its effect in the yield and quality of soybean seeds. J Agric Sci. 10: 518-526.

Gasparetto R, Fernandes CD, Marchi CE, Borges MF (2011) Eficiência e viabilidade econômica da aplicação de fungicidas no controle da ferrugem asiática da soja em Campo Grande, MS. Arq do Inst de Biol. 78(2): 251-260.

Godoy CV, Canteri MG (2004) Efeitos protetor, curativo e erradicante de fungicidas no controle da ferrugem da soja causada por Phakopsorapachyrhizi, em casa de vegetação. Fitopat Brasi. 29(1): 97-101.

Juliatti FC, Balardin RS, Martins JAS, Rezende AA Lentz G (2010) Resistência genética da soja à Phakopsorapachyrhizi e uso de fungicidas no manejo sustentável da doença. Rev Anual de Pato de Plant. 8(1): 77-118.

Maluf JRT (2000) Nova classificação climática do Estado do Rio Grande do Sul. Ver Bras de Agromet. 8(1): 41-150. 
Meier C, Meira D, Olivoto T, Follmann DN, Nardino $M$, Carvalho IR, Ferrari M, Pelegrin AJ, Szareski VJ, Souza VQ (2016) Morphological traits and yield components of second-crop soy beans in Rio Grande do Sul state, Brazil. Aust J Basic Appl Sci. 9:81-88.

Oliveira AMA (2002) Efeito da aplicação foliar de fungicida sobre caracteres agronômicos, qualidade fisiológica e sanidade de sementes de soja (Glycinemax (L.) Merrill). Universidade Federal de Viçosa, Viçosa, Dissertation (Masters).

Pelegrin AJ, Carvalho IR, Nardino M, Ferrari M, Szareski VJ, Belle R, Meira D, Souza VQ (2016) Performance of resistant soybean to Asian Rust in different environments in RS. Int J Curr Res. 8: 38398-38401.

Pelegrin AJ, Nardino M, Ferrari M, Carvalho IR, Szareski VJ, Belle R, Caron BO, Souza VQ (2017) Hydroretentor polymers in soybean in Latosol conditions of Rio Grande do Sul. Revista de Ciências Agrárias. 40: 175-182.

Pimentel Gomes F (2009)Curso de estatística experimental. 14 ed. Piracicaba: Degaspari.

Rigo GA, Scuch LOB, Vargas RL, Barros WS, Szareski VJ. Carvalho IR, Troyjack C, Pimentel JR, Escalera RAV, Da Rosa TC, Souza VQ, Aumonde TZ, Pedo T (2018) Micronutrient content and physiological quality of soybean seeds. J Agric Sci. 10: 223-230.

Rigo GA, Schuch LOB, Barros WS, Vargas RL, Szareski VJ, Carvalho IR, Pimentel JR, Troyjack C, Jaques LA, Rosa TC, Souza VQ, Aumonde TZ, Pedo T (2018) Effects of macronutrients in the physiological quality of soybean seeds. J Agric Sci. 10: 312-318.

Silva OC, Schipanski CA, Veiga J (2007) Obstáculo à produção. Caderno técnico doenças circula encartado na revista: Cultivar Grandes Culturas. 94: 3-10.

Sinclair JB, Hartman GL (1995) Management of Soybean Rust.In: Soybean rust workshop. Proceedings. Urbana: College of Agricultural, Consumer and Environmental Sciences. 6-10
Szareski VJ, Carvalho IR, Nardino M, Demari G, Bahry CA, Kehl K, Pedo T, Zimmer PD, Souza VQ,Aumonde TZ (2016)Phenotype stability of soybean genotypes for characters related to the physiological quality of seeds produced under different environmentall conditions. Aust J Bas and App Sci. 10: 279-289.

Szareski VJ,Carvalho IR, Nardino M, Pelegrin AJ, Ferrari M, Gaviraghi R, Demari G, Follmann DN, Warths CA, Souza VQ(2016)Competition of soybean genotypes cultivated in lowlands of Rio Grande do Sul, Brazil. Int J Cur Res. 8: 39714-39718.

Szareski VJ, Carvalho IR, Kehl K, Levien AM, Nardino M, Dellagostin SM, Demari GH, Lautenchleger F, Villela FA, Pedo T, Souza VQ, Aumonde TZ (2018) Evaluation of the adaptability and stability of wheat genotypes using a phenotypic index of seed vigor. Pesquisa Agropecuária Brasileira. 53(6): 727-735.

Szareski VJ, Ferrari M, Nardino M, Carvalho IR, Pelegrin AJ, Demari GH, Follmann DN, Meira D, Meier C, Souza VQ (2017) Performance de fertilizantes foliares e correlações lineares em componentes do rendimento da soja. Revista UniVap. 22, 443.

Vargas RL, Schuch LOB, Barros WS, Rigo GA, Szareski VJ, Carvalho, IR, Pimentel JR, Troyjack C, Souza VQ, Rosa TC, Aumonde TZ, Pedo T (2018) Macronutrients and micronutrients variability in soybean seeds. J Agric Sci. 10: 209-222.

Yorinori JT (1986)Doenças da soja no Brasil. In: Fundação Cargill. Soja no Brasil Central. Campinas: Fundação Cargill301-363.

Zanatta E, Szareski VJ, Carvalho IR, Pimentel JR, Troyjack C, Dellagostin SM, Demari G, Lautenchleger F, Souza VQ, Martinazzo EG, Villela FA, Aumonde TZ (2018) PreharvestDesiccation: Productivity and physical and physiological inferences on soybean seeds during storage. J Agric Sci. 10: 354-362.

Zimmer G, Koch F, Carvalho IR, Szareski VJ, Demari GH, Nardino M, Follmann DN, Souza VQ, Aumonde TZ, Pedo T (2016) Seed quality and initial performance os seedlings of soybean produced off-season in Rio Grande do Sul, Brasil. Int J Curr Res. 8: 40325-40329. 